\title{
AS METAMORFOSES IDEOLÓGICAS DO PENSAMENTO BRITÂNICO SETECENTISTA Do republicanismo de Bolingbroke ao liberalismo de Burke (1720-1770)
}

\section{Christian Edward Cyril Lynch (1)}

(D) https://orcid.org/0000-0001-5709-9388

\section{Paulo Henrique Paschoeto Cassimiro}

(1) https://orcid.org/0000-0003-2986-6580

(1) Instituto de Estudos Sociais e Políticos (Iesp-Uerj); Fundação Casa de Rui Barbosa (FCRB); Universidade Veiga de Almeida (UVA); Instituto Histórico e Geográfico (IHGB), Rio de Janeiro - RJ, Brasil. E-mail: clynch@iesp.uerj.br

(2)Universidade de Sáo Paulo (USP), São Paulo - SP, Brasil. E-mail: phpcassimiro@gmail.com

DOI $10.1590 / 3510217 / 2020$

\section{Introdução}

Durante décadas predominou na teoria política a interpretação do liberalismo - ideologia dominante na modernidade - como a vitória da dimensão privada, do interesse econômico e do individualismo contra ideologias políticas que valorizavam a vida ativa do cidadão na comunidade política. A interpretação clássica de Isaiah Berlin - em seu ensaio denominado Dois conceitos de liberdade - cristalizou a noção de que a liberdade negativa, como movimento inicial e fundamental da liberdade moderna, representaria a manutenção das garantias do indivíduo contra o Estado. A partir daí, muitas leituras do conceito de liberdade negativa atribuíram ao liberalismo a afirmação de uma vida individual que se realizaria, sobretudo, contra a politica; que o liberalismo

Artigo recebido em: 10/02/2019

Aprovado em: 17/10/2019 justificaria ideologicamente a liberdade de mercado; e que o predomínio do indivíduo esvaziaria a política em favor do espaço privado. Esse é o argumento que subjaz à célebre interpretação de C. B. Macpherson sobre o liberalismo em sua obra The political theory of possessive individualism: from Hobbes to Locke, publicada cinco anos após o referido trabalho de Berlin. Essa vinculação entre cultura política liberal e individualismo/mercado resultou em um conjunto de interpretaçóes que opunham sistematicamente o liberalismo à tradição republicana, que passaria pela defesa permanente do vínculo entre liberdade e participação política. A obra de Quentin Skinner, Liberty before liberalism, por exemplo, tenta demonstrar como a "compreensão neorromana da liberdade civil" foi derrotada pela "hegemonia liberal" a partir do século XVIII (Skinner, 2012, p. x). Skinner ilustra a partir de Berlin esse "eclipse" da "teoria neorromana de homens e Estados livres", recriminando a liberdade negativa por seu suposto descompromisso com a 
democracia: "A liberdade negativa não é incompatível com certos tipos de modelos autocráticos, e de forma alguma com a ausência de autogoverno" (Skinner, 2012, p. 115).

Ocorre que a hipótese de Skinner vem sendo problematizada, e com razão, não tanto acerca da preexistência de uma linguagem anterior e hegemônica de liberdade, mas na insistência em sua oposição fundamental entre ambas. Propondo uma alternativa, autores como Nadia Urbinati, Andreas Kalyvas e Ira Katznelson têm insistido que certas tradiçóes do liberalismo (político, sobretudo) podem ser entendidas no interior das transformaçóes da linguagem republicana (Urbinati, 2012; Kalyvas e Katznelson, 2008). Os dois últimos intérpretes, por exemplo, revelam como um conjunto de autores tradicionalmente identificados com a ascensão do liberalismo - entre os quais Adam Smith, Adam Ferguson, Germaine de Staël e Benjamin Constant - transformam gradualmente a antiga linguagem republicana a partir da necessidade de legitimar a expansão da dimensão do interesse privado nos quadros da vida comunitária.

Sem comprometer os princípios republicanos ou abandonar uma linguagem republicana, essa tradição não poderia lidar com sucesso com uma série de problemas prementes sem uma revisão. Para remediar essa circunstância, pensadores contemporâneos transformaram recursos republicanos existentes e, quando necessário, expandiram seus limites para além dos limites conceituais e institucionais do republicanismo, introduzindo novos princípios e argumentos retirados de outras correntes intelectuais e filosóficas [...]. Essas emendas e sinergias produziram o liberalismo constitucional, não como uma alternativa ao republicanismo clássico, mas, de forma significante, como uma doutrina incubada nele. O liberalismo político brotou da casca de uma crisálida republicana (Kalyvas e Katznelson, 2008, p. 5).

O presente artigo não pretende concentrar-se no debate teórico entre a liberdade negativa e a liberdade como não dominação, mas antes explorar historicamente, no caso específico do pensamento britânico setecentista, as continuidades e rupturas entre as linguagens republicanas e liberais. Diferentemente do que Skinner sugere, o que se verifica historicamente é uma modificação molecular do republicanismo naquilo que se chamará liberalismo na virada do século XVII para o XVIII, por força das mudanças decorrentes da ascensão da sociedade comercial. A hipótese está sugerida na obra de John Pocock e o intuito aqui é o de aprofundá-la. O artigo entende que, em Liberty before liberalism, Skinner estava interessado em transitar da história do pensamento para a filosofia política, movimento que deu origem ao debate teórico-filosófico sobre o republicanismo a que se juntaram Maurizio Viroli, Philip Petit e outros. Embora tais autores se valham de elementos colhidos da história do pensamento político para pensar de forma abstrata uma "filosofia política" do republicanismo, com aspiraçóes mais abrangentes, o que se percebe é que, nesse debate, eles ajudaram a cristalizar arquétipos de republicanismo e de liberalismo frequentemente descolados de uma abordagem mais propriamente histórica. Conforme ponderado por Ian Hampsher-Monk (in Skinner e Van Gelderen, 2002, p. 90), como toda linguagem política (e não como conceitos filosóficos estáveis), o republicanismo apresentava uma textura conceitual e retórica aberta, sendo capaz de ser valorizada e explorada de diversas maneiras. Blair Worden (in Skinner e Van Gelderen, 2002 , p. 90) vai além quando afirma que nenhuma definição única de republicanismo pode reivindicar autenticidade histórica em si mesma. A oposição à monarquia, por exemplo, existia apenas quando ela fosse tirânica, sendo considerada forma de república - isto é, de governo livre -, sempre que virtuosa e compatível com a liberdade dos súditos. Durante o reinado de Elizabeth I, clássicos como Cícero, Lívio, Tácito e Plutarco serviam tanto para elogiar o cidadão Bruto quanto o imperador Augusto (ibidem, pp. 310-312). Fenômeno que se repetiria após a Revolução Gloriosa.

Criada a partir da herança aristotélica por romanos como Políbio, Cícero e Tito Lívio, a linguagem do republicanismo cívico havia sido recuperada na Renascença por autores como Maquiavel e Guicciardini na Itália, e depois por Harrington e Sidney na Inglaterra. Os republicanos vituperavam 
a tirania e cogitavam das formas por que poderiam organizar uma comunidade política a partir do ideal da república romana. Como os antigos, aproveitando a experiência da história, mestra da vida, os republicanos acreditavam que deveriam viver sem sombra de poder arbitrário. A liberdade dependia da participação dos cidadãos nos negócios públicos, da ausência de impedimentos externos e da submissão de todos às leis da república. Recuperaram assim o apreço pela virtude cívica e o compromisso com a vida ativa, com seus atributos de frugalidade, patriotismo e integridade. Recuperaram também o ideal da constituição mista como a única própria para limitar e balancear o poder, submetendo os governantes ao império da lei (Pocock, 1997; Bignotto, 2001, p. 199; 2006, p. 106; Skinner, 2012, p. 65; Maddox in Ball, Farr e Hanson, 1989, p. 59; Quintana, 2014, pp. 72-73). Adequadamente assegurado por um governo misto de monarquia, aristocracia e democracia, o regime republicano equilibrava o desejo dos governantes em oprimir com o desejo dos governados de liberdade, permitindo que o conflito político se desenrolasse sem risco de subversão. A corrupção seguia como o principal elemento de corrosão da virtude da república, provocada pela prevalência do particularismo sobre o bem comum, quase sempre manifesto pela vontade irrefreável de poder dos poderosos. Daí porque o combate ao luxo e o amor à frugalidade, pelos exemplos, pelo culto religioso e pela educaçáo cívica e militar, deveriam ser incentivados continuamente a fim de manter os cidadãos dentro do círculo da virtude e da solidariedade.

Partindo de tais premissas, o artigo fugirá das discussões relativas à caracterização do republicanismo, centradas na Itália renascentista ou na Inglaterra da guerra civil, para focar na primeira metade do século XVIII britânico. Retomando as intuiçôes de John Pocock, Andreas Kalyvas e Ira Katznelson, o intuito é o de explorar as dinâmicas próprias do "momento oligárquico" inglês, isto é, do período entre a consolidação da limitação da autoridade real pelo Parlamento em 1688 até a expansão do sufrágio a partir de 1832. Esta foi a época em que a ascensão da sociedade comercial e do império britânico desafiaram a linguagem republicana herdada da época de enfrentamento do absolutismo. $\mathrm{O}$ argumento aqui é o de que foi a necessidade de defender a nova sociedade moderna, identificada com o gabinete Walpole, contra os ataques promovidos pelos republicanos liderados por Bolingbroke, que o acusavam de corromper a Constituição da Grã-Bretanha, que levaram os governistas a adaptar a linguagem republicana aos novos tempos, marcados pelos valores comerciais, exércitos profissionais, mercado mobiliário, partidos parlamentares etc. De um lado, a retomada de certo tipo de republicanismo maquiaveliano adversário do regime oligárquico apela ao protagonismo da coroa; do outro, a defesa das transformaçóes sociais e econômicas conduz à elaboração de uma linguagem política que acusa o republicanismo antigo de anacronismo e aponta a necessária convivência entre o indivíduo privado e o cidadáo na modernidade. E que, ao proceder a essa adaptação, autores como Hume e Burke deram os primeiros passos no sentido de reelaborar temas das linguagens republicanas a partir de problemas colocados pelas transformaçôes $\mathrm{da}$ modernidade, formulando soluçóes que futuramente seriam identificadas com o liberalismo político. O debate ilustra uma transformação central para a emergência das linguagens que constituiriam as ideologias predominantes da época atual.

\section{O "momento oligárquico" inglês: a monarquia constitucional e o bipartidarismo}

A Revolução Gloriosa consumou a revolução oligárquica inglesa. Com a fuga do rei Jaime II, os novos reis - sua filha protestante, Maria, e seu marido, Guilherme III, príncipe de Orange - se comprometeram com a "antiga Constituição", confirmada pelo Parlamento com uma série de leis que afastaram definitivamente o fantasma do absolutismo católico. O mais importante estatuto do novo "momento oligárquico" foi a Declaração de Direitos (Bill of Rights) (1689), que limitou a prerrogativa ao proibir a Coroa de suspender leis; criar impostos, tribunais especiais ou levantar exércitos em tempos de paz; firmou o direito que os súditos tinham de peticionar e guardar armas; obrigou à regularidade na convocaçáo do Parlamento; assegurou a liberdade eleitoral e a imunidade de seus membros; e consagrou princípios como os da proporcionalidade 
tributária; o julgamento por júri e o devido processo legal. Seguiram-se o Decreto da Tolerância (1689), que garantiu a liberdade de consciência para todos os protestantes; o Decreto Trienal (1694), que obrigou a Coroa a convocar o Parlamento pelo menos a cada três anos; o Decreto sobre a Liberdade de Imprensa, que extinguiu a censura prévia aos impressos (1695); o Decreto sobre Traição (1696), que proibiu o governo de enquadrar seus adversários naquele tipo penal; o Decreto de Estabelecimento (1701), que fixou a linha de sucessão nos príncipes protestantes da dinastia Stuart e, na ausência deles, nos descendentes da princesa eleitora de Hannover; e, por fim, o Decreto de União com a Escócia (1707), que criou o Reino Unido da Grã-Bretanha.

O "momento oligárquico" só entraria em declínio com a Primeira Reforma Eleitoral (1832) que expandiria o sufrágio e o número de distritos eleitorais. Fixou-se por esse tempo o entendimento que a Constituição da Inglaterra, entendida como arquétipo de um Estado de direito, era um sistema de instituições sociais e políticas mantidas em equilíbrio por um governo misto, cujos principais traços eram a relevância do monarca e da influência da Coroa; a dominação do Parlamento por uma elite rural e aristocrática; eleiçóes marcadas pelo patronato e pela influência dos notáveis; e a sobrevivência de antigas instituiçóes locais de governo; e o conservadorismo ou moderantismo das elites proprietárias (Dickinson, 2002, pp. 3-17; O’Gorman, 1997, pp. 29-36). Na prática, o centro político deslocou-se da pessoa do governante para o Parlamento. Das duas casas que o compunham, a dos Pares ou Lordes era considerada o "pilar da Constituição". Fiadora institucional do governo misto, a câmara alta era o esteio da Coroa, que dela extraía seus principais ministros. Os nobres que nela tinham assento formavam um seletíssimo grupo social que, em torno de 1750 , não reunia mais de 150 famílias. Eles detinham vastas propriedades rurais, cuja riqueza lhes assegurava influência social, e um padrão de vida compatível com seus títulos de nobreza. Pertenciam a famílias tradicionais, tinham uma educação respeitável e casavam-se com membros do mesmo estrato social. A ele pertenciam ainda quase trinta bispos da Igreja Anglicana, que tendiam a se manifestar apenas em matéria eclesiástica (Beckett e Jones in Jones, 1989, pp. 1-19).
Ao longo da década anterior à Revolução, a dinâmica política começara a ser pautada pela existência de dois partidos parlamentares. O primeiro, denominado whig ou "do campo", defendia a Constituição mista e se opunha à ascensão de Jaime II; o segundo, chamado tory ou "da corte", defendia o absolutismo anglicano de direito divino. Depois da Revolução Gloriosa, a ala radical whig alegou que o rei violara o contrato com o povo, fato que autorizara sua deposição e substituição por Maria e Guilherme III, príncipes que haviam jurado a Declaração de Direitos para assumirem o trono. A ala radical tory manteve-se fiel aos reis depostos, acusando a usurpação e apoiando as pretensóes da dinastia decaída por mais meio século. Mas os moderados eram mais numerosos e foram eles que formaram a base de sustentação do novo regime. Do ponto de vista narrativo, a classe política preferiu abraçar a linguagem do constitucionalismo antigo, para o qual a Revolução havia sido uma simples restauração da antiga Constituição que custara uma pequena alteração da linha sucessória do trono (Tully in Skinner e Philipson, 1993, p. 259). Estruturou-se uma cultura política bipartidária, cujas divergências não questionavam a entendimento básico da Constituição como o de uma antiga monarquia mista que consagrava as liberdades de seus cidadãos (Bailyn, 2003, p. 250). As diferenças ficavam no interior dessa moldura, restritas ao plano da interpretação. Os whigs da primeira metade do século entendiam que a supremacia do Executivo era possível desde que ele obtivesse maioria no Legislativo; ao passo que os tories sustentavam que os poderes deveriam ser radicalmente independentes para preservar o equilíbrio do governo misto (Goldie in Goldie e Wokler, 2008, p. 65).

Os discursos whigs e tories começaram a ser reconfigurados ainda na década de 1690, com a subida dos primeiros ao poder. Desejosa de satisfazer a ambição de Guilherme III de engajar a Inglaterra nas guerras contra a França, a nova situação whig patrocinou uma reconstrução do sistema tributário que, ao longo do século seguinte, aumentou quinze vezes a arrecadação e tornou o país mais sobretaxado da Europa. A fundação do Banco da Inglaterra (1694) e a canalização dos recursos financeiros da City para o Tesouro criaram um sistema nacional de dívida e de crédito públicos que expandiu ainda mais a 
capacidade de financiamento do Estado. Assustada com o crescimento da burocracia, da corrupção e do exército profissional, a minoria tory na oposiçấo reafirmou seu compromisso com o ideal republicano de uma comunidade de proprietários fundiários independentes, cuja estabilidade dependia de arranjos fundados no princípio material da propriedade de terra. Após um interlúdio oposicionista sob o reinado de Ana (1702-1714), os whigs voltaram ao poder com a dinastia de Hannover e promoveram o Decreto Septenal (1716), que ampliou a duração das legislaturas de três para sete anos a fim de "esfriar" o sistema político. Durante esse longo tempo de hegemonia whig, que durou cerca de meio século, conforme bem descrito por Pocock em seu texto clássico Variaçôes sobre o whiguismo, o republicanismo deixou de ser abraçado pelos whigs e passou a ser albergado pelos tories, o que sugere que aquela linguagem se tornara principalmente um idioma de oposição e, como tal, passível de ser mobilizado por quem nela se encontrasse. Assim como parte significativa dos whigs na última década da dinastia Stuart mobilizava o republicanismo contra a "tirania" de Carlos II e Jaime II, depois da Revolução Gloriosa e a consolidação da oligarquia whig no poder, quando da ascensão da dinastia de Hannover, foi a maioria do partido tory que - posta em longevo ostracismo e liderada por Bolingbrokepassou a exprimir-se na oposição através da linguagem do republicanismo cívico.

A estabilidade do regime oligárquico whig firmou-se durante o longevo gabinete chefiado por Sir Robert Walpole (1721-1745). Ele convenceu a Coroa de que os tories pretendiam restaurar o absolutismo e só os whigs podiam consolidar a nova dinastia; assegurou a maioria parlamentar por um modelo de governabilidade baseado no emprego de práticas "fisiológicas" ou clientelistas; e, por fim, aprovou reformas que aumentavam a influência eleitoral do governo, desestimulando a participação e a competição. Aconteceu entáo uma inversão de posições ideológicas: a maioria whig assumiu o lugar de partido da Corte, justificando as políticas conservadoras e oligárquicas da Coroa, enquanto a maioria tory assumiu o discurso do partido do Campo, exprimindo a indignaçáo da pequena nobreza rural com a corrupção e a ciranda financeira (Hellmuth in Dickinson, 2002, p. 21; O’Brien in Dickinson, 2002, p. 35; Pocock, 1997 , p. 431; Black, 2001, pp. 9 e 66-80; O'Gorman, 1997, p. 139; Hill in Dickinson, 2002, pp. 58-64; Jones e Beckett in Jones, 1989, p. 96).

$\mathrm{O}$ debate sobre o lugar da virtude numa sociedade dominada cada vez mais pela indiferença cívica e pelo interesse econômico foi afetado pela famosa querela entre antigos e modernos, cuja versão inglesa ficou conhecida como a "batalha dos livros". $\mathrm{O}$ resgate do classicismo à época do Renascimento produzira um paradoxo: de um lado, os humanistas ressuscitavam os clássicos para imitá-los; por outro, a fim de reproduzir seus valores e artes no presente, desenvolveram técnicas e métodos de filologia que revelavam um passado cada vez mais distante do presente, cujas referências pareciam impróprias ou obsoletas em certos aspectos (Levine, 1999, p. 22). $\mathrm{O}$ horizonte de expectativas em relação à tradiçấo ampliava-se e, com ele, o espaço para a liberdade e a invenção, bem como a ideia de progresso histórico. Politicamente, tornou-se possível justificar as mudanças operadas pela "revolução financeira", recorrendo-se a um arsenal de argumentos mais ou menos inéditos, fato que levou à emergência de duas diferentes interpretaçôes da Constituição. A primeira, "clássica" ou republicana, tinha pressupostos aristocráticos pré-capitalistas. Estava baseada no ideal de uma comunidade formada por cidadáos, cuja posse de uma propriedade rural lhes facultava o cultivo da virtude necessária à preservaçáo da liberdade e da participação política contra a tirania. A segunda interpretação, "moderna" ou liberal, apresentava pressupostos capitalistas e partia da realidade de uma sociedade comercial urbana e rentista, cujos membros deixavam os afazeres políticos a cargo de representantes associados em partidos e voltavam suas liberdades para o gozo de atividades privadas.

\section{Ideologias do "momento oligárquico" britânico (1): Bolingbroke e a interpretaçáo "clássica" ou republicana da Constituiçáo da Inglaterra}

Conforme reconhecido por autores como Jeremy Black, David Armitage e John Pocock, a interpretação da Constituição da Inglaterra, fundada no ideal clássico de uma "monarquia republicana", encontrou 
sua versão mais acabada na primeira metade do século XVIII na obra de Henry St. John, visconde de Bolingbroke (1678-1751), chefe do partido tory na oposição contra o governo Walpole (Black, 2001, p. 141; Armitage, 2002, p. 41; Pocock, 1985, pp. 235-240; 1997, pp. 488-489). Ele produziu na década de 1730 três textos fundamentais, cada qual dirigido a uma das ordens da Constituição: os comuns, os aristocratas e o monarca. Dirigido aos membros do Parlamento, Uma dissertação sobre os partidos negava a divisão do país entre whigs e tories, acusada por Walpole para redefini-la como uma luta entre as tendências tirânicas do partido da Corte e o patriotismo do partido do Campo ou do país. A mocidade aristocrática foi mobilizada para confrontar a situação whig (o "partido da Corte") por meio da carta Sobre o espirito do patriotismo, guia para o estadista à maneira de Cícero, civicamente orientado, ambicioso de glória e devotado à pátria. Por fim, diante da descrença na possibilidade de reverter a decadência dos costumes do país, Bolingbroke apelou para o herdeiro da Coroa, escrevendo um espelho de príncipe constitucional, $A$ ideia de um rei patriota. Foi a versão inglesa do apelo ao rei filósofo como remédio aos males públicos que atormentavam a existência da comunidade política e pareciam incuráveis pelas vias ordinárias (Goldie in Goldie e Wokler, 2008, p. 73). Nesse texto, o visconde defendeu o dever que tinha o monarca de, em circunstâncias de risco para a constituição, intervir na política para, por meio de um golpe constitucional, substituir os ministros facciosos por estadistas que fossem modelos de sabedoria, austeridade e virtude. As numerosas edições das obras de Bolingbroke reverberaram na Inglaterra, na América e na Europa, influenciando um sem-número de estadistas interessados em remodelar o governo de seus países de acordo com o figurino constitucional (Armitage in Bolingbroke, 1997, p. 38).

A primeira parte da Dissertação investigava as origens do sistema partidário no século XVII, época em que os Stuart teriam organizado um "partido da Corte" para abater o Parlamento e, com ele, a antiga Constituição. Socorrendo-se de Políbio, Cicero, Lívio, Sêneca, Tácito e Maquiavel (seu autor favorito), o visconde condenava os partidos como calamidades cívicas: seus membros eram "incapazes de amizade; porque a verdadeira amizade não pode existir entre aqueles que baniram de si a virtude e a verdade. Eles não têm afeição senão por si mesmos; nenhum interesse exceto os seus". Contra esse partido, na defesa da Constituição, teriam se organizado os cidadãos virtuosos no chamado "partido do Campo" ou "do país", que náo era propriamente um partido, e sim "a nação, falando e agindo por intermédio do discurso e da conduta de determinados homens" (Bolingbroke, 1997, pp. 22-29, 37 e 99). O partido da Corte lograra dividir a nação entre whigs e tories, alimentando as paixóes para que se acusassem daquilo que não eram, ou seja, revolucionários e absolutistas. Entretanto, diante do perigo de restauração católica, os moderados teriam se conciliado na Revolução Gloriosa para restabelecer o espírito e os princípios da Constituição, conforme a natureza e os verdadeiros fins do governo. Restaurada a forma de governo em bases seguras e inequívocas, na forma de um padrão legal e ético reconhecido por todos, Bolingbroke entendia que a divisão da sociedade entre os partidos whig e tory se tornara desnecessária e artificial. Se a sociedade podia ter por base uma constituição fundada na razão natural e no bem comum, sua organização social devia ser apartidária para ser sadia (Mansfield, 2013, p. 64).

A segunda parte da Dissertaçâo descrevia a natureza e os contornos da Constituição mista. Citando Maquiavel, Bolingbroke afirmava que, embora poucos devessem governar muitos, o governo era sempre tensionado pela luta entre "o espírito de liberdade" do povo e "o espírito de dominação" dos governantes. Dessa tensão surgira o governo constitucional: da necessidade de conter a multidão turbulenta surgira o governo, e a Constituição, do imperativo de conter sua tendência ao arbítrio. $\mathrm{O}$ engenho humano podia criar instituiçóes favoráveis à liberdade e ao exercício da cidadania: uma vez que as constituiçóes puras - monarquia, aristocracia e democracia - inclinavam-se para a tirania, apenas a mista revelava-se capaz de produzir um governo virtuoso e estável. Só o governo misto proporcionava "liberdade verdadeira, ou seja, liberdade declarada e garantida pela lei, em igual oposição à licença popular e à vontade arbitrária do governante". A organização mista era a fórmula da união nacional, porque reunia as diferentes 
ordens enquanto "partes de um mesmo sistema, intimamente ligados e cooperativos, influenciando e sendo influenciados, controlando e sendo controlados uns pelos outros”. Assim como Políbio descrevera a Constituição de Roma como um aperfeiçoamento da espartana, Bolingbroke descrevia a Constituição da Inglaterra como um aperfeiçoamento da romana promovido pelos germânicos, heroicos e virtuosos antepassados dos ingleses: "É por meio dessa mistura de monarquia, aristocracia e democracia, reunidas em um único sistema, no qual cada uma das três ordens equilibra a outra, que nossa Constituição livre de governo tem se mantido por tanto tempo inviolada, ou retornada, depois de sofrer violaçôes, aos seus princípios originários" (Bolingbroke, 1997, pp. 83, 112, 126-127 e 132). O exercício da soberania ficava a cargo do Parlamento, órgão composto pela nobreza e pela plebe. $\mathrm{Na}$ qualidade de ordem intermediária, a aristocracia servia de poder arbitral entre rei e plebe. $\mathrm{O}$ monarca náo passava de um primeiro magistrado designado em confiança para o exercício das funçóes do governo.

Mas a Constituição da Inglaterra também era uma fórmula jurídica que limitava e condicionava o exercício do governo. Aqui Bolingbroke distinguia os dois conceitos. A Constituiçáo era o "conjunto de leis, instituiçóes e costumes, derivados de certos princípios fixos da razão, dirigidos a certos objetos determinados de bem comum, que compóe o sistema geral, de acordo com o qual uma comunidade concordou em ser governada”. Já o governo consistia "no particular modo de conduta que um magistrado principal, e magistrados inferiores sob sua direção e influência, conduzem a administração dos negócios públicos". Por serem organizaçóes efêmeras, formadas por homens sujeitos a paixóes e inclinados à tirania, os governos precisavam se pautar pela mais estrita conformidade com a Constituiçãa, cujos princípios e objetivos traduziam o ideal natural e permanente de supremacia do bem comum: "Constituição é a regra por que nossos príncipes devem governar em qualquer época; governo é a regra por que eles realmente governam em determinado momento. Uma deve permanecer imutável, enquanto a outra pode e - por sua natureza humana - deve variar". Mas os Parlamentos também estavam sujeitos à
Constituição, não podendo modificá-la; embora supremos, também estavam limitados pelo "bem comum da sociedade" (Bolingbroke, 1997, pp. 88 e 165). Parlamentos eram baluartes da Constituição, e sua autonomia dependia de sua reunião periódica contra a dependência arbitrária da vontade da Coroa; uma vez que a revoluçáo garantia aquela periodicidade, tornara-se desnecessário o "apelo aos céus" referido por Locke.

Uma vez que a Constituição se encontrava assentada, uma facção só poderia derrocá-la caso corrompesse o Parlamento. Era o que, segundo Bolingbroke, Walpole estava fazendo. As liberdades parlamentares dependiam de eleiçóes que renovassem a deputação uma vez a cada um ou três anos, tornando-as insuscetíveis de cooptação pela corrupção governamental. Ele também condenava como inconstitucional o modelo de governo criado por Walpole, que garantia maioria parlamentar com a distribuição de pensóes, subornos e cargos públicos. O sistema de freios e contrapesos e de separação de poderes era insuscetível de alteração pelo governo e não podia ser modificado a pretexto de embaraçar a governabilidade. A facção áulica erigia-se assim em um novo "partido da Corte", que perseguia o velho objetivo de minar a autonomia do Parlamento para governar tiranicamente. Mudaram apenas os meios: ao invés de recorrer à prerrogativa para impedir a reuniāo dos parlamentares, Walpole empregava a corrupção para controlá-los. $\mathrm{O}$ arrocho fiscal, a expansão do Estado, a manutenção de exércitos profissionais e a ciranda financeira eram outros tantos instrumentos por que a camarilha da corte desequilibrava os elementos do governo misto para derrubar a Constituição da Inglaterra. Caso os cidadãos não mantivessem vivo o "espírito patriótico" de seus antepassados saxôes, sua comunidade sofreria o mesmo infausto destino da república romana, sucumbindo pela corrupção à tirania de um César. Só um governo de união nacional, baseado em uma conciliação que dissolvesse a divisão entre tories e whigs, poderia volver aos princípios germânicos e republicanos da Constituiçáo e interromper o processo de sua degeneração.

Assim como a liberdade privada não pode estar segura sob um governo no qual a lei, que é sua única e adequada garantia, dependa do arbítrio de 
uma vontade, também a liberdade pública estará em perigo, sempre que uma Constituição livre, que é sua única e adequada garantia, dependa do arbítrio de uma vontade. Uma Constituição livre como a nossa também estará dependente dessa vontade, sempre que uma das três ordens que a compóe possa direcionar a vontade das demais (Bolingbroke, 1997, p. 170).

Mas quais seriam os agentes privilegiados encarregados de combater o novo partido da corte? Como eles deveriam agir? Quais qualidades deveriam ter? Se, na Dissertação, Bolingbroke associava as açôes da facção governamental à ambição, ao egoísmo e à corrupção, na carta denominada Sobre o espirito do patriotismo (1736), o visconde delineava o perfil dos patriotas que deveriam liderar a oposição em nome do partido do Campo ou do pais. Em primeiro lugar, Bolingbroke lembrava que a arte da política náo estava ao acesso de qualquer um; que a política náo era atividade de profissionais, e sim de uma aristocracia de talentos (Mansfield, 2013, pp. 68 e 74). Ela destinava-se aos predestinados que a Providência bafejara com uma natural superioridade de espírito para que pudessem instruir, guiar e preservar a humanidade. Os aristocratas vocacionados estavam moralmente obrigados a colocar a serviço do país as vantagens de seu alto nascimento, sua fortuna material e sua superioridade intelectual; na condição de "tutores e guardiāes do gênero humano", estavam encarregados de manter a ordem natural do mundo. O espirito de patriotismo que dava vida à Constituição dependia da ação de estadistas que houvessem adquirido conhecimento político pelo estudo da história e da filosofia e mobilizassem sua eloquência para persuadir seus concidadãos, à maneira de Demóstenes e Cícero. $\mathrm{O}$ verdadeiro patriota era aquele que, como Catão, empregava "toda a força de seu entendimento e dirigia todos os seus pensamentos e açóes para o bem de seu país" (Bolingbroke, 1997, pp. 193, 201 e 203). Náo havia maior glória do que despender a sua vida na defesa da liberdade pública, no combate ao mau governo e na sustentação do bom, de modo a oferecer à juventude exemplos de virtude e dedicação. Era de gente como essa à frente do partido do Campo que dependia a salvação da república contra a maquinação dos Catilinas e suas aspiraçóes à tirania. Nem por isso dever-se-ia descartar a hipótese de que nem comuns nem pares fossem capazes de refrear o espraiamento da corrupção que derrubara Roma. Haveria, nesse caso, algum expediente a que recorrer?

Maquiavel ensinara que, em circunstâncias de perigo, somente um remédio excepcional desferido do alto, na forma de um golpe violento e súbito, poderia fulminar a corrupçấo e criar condiçôes para o restabelecimento da liberdade. Ora, o único em posição de desfechar semelhante golpe era a autoridade suprema que, acima dos partidos responsáveis pela decadência cívica do país, estivesse interessado na preservação da Constituição. Desejando sensibilizar o herdeiro do trono, Bolingbroke escreveu o primeiro espelho de príncipe destinado a um chefe constitucional: $A$ ideia de um rei patriota (1738). A releitura de Maquiavel levava-o a perceber o príncipe constitucional como dotado de virtualidades que poderiam excepcionalmente incumbi-lo de exercer um papel diverso daquele de um mero encarregado do Poder Executivo. Ele ressuscitou então as noções de razáo de Estado e golpe de Estado, típicas da "revolução monárquica", para mobilizá-la, não contra, mas a favor da restauração da Constituição mista. Tratava-se de dirigir as ambiçōes de domínio do príncipe maquiaveliano para o patriótico propósito de defender a república. $\mathrm{Na}$ condiçáo de chave de abóbada do sistema constitucional, o monarca deveria defender a Constituição e restabelecê-la sempre que abalada pela iniquidade administrativa: "Nada pode, com tanta certeza, de modo tão eficiente, restaurar a virtude e o espírito público essencial para preservação da liberdade e da prosperidade nacional do que o reinado de semelhante príncipe" (Bolingbroke, 1997, p. 222). A ascensão de um príncipe novo era a ocasiāo perfeita para desfechar semelhante golpe, substituindo os ministros corrompidos por estadistas que fossem exemplos de austeridade e virtude: "Esse esquema de razão de Estado contém todos os grandes princípios do governo e todos os grandes interesses do Estado" (Bolingbroke, 1997, p. 252). As limitaçôes ao poder só prejudicavam os reis de inclinaçôes tirânicas. Os reis patriotas, ao contrário, adquiriam, pela defesa da Constituição sobre os partidos, uma força e uma influência superiores às de qualquer governante absoluto: 
O Rei patriota é o mais poderoso de todos os reformadores. E, porque ele é uma espécie de milagre permanente, raramente visto e tão pouco compreendido, que bastam os efeitos de seu surgimento para que ele suscite, por toda a parte, o amor e a consideração em todo coração honesto, difundindo confusão e terror em todas as consciências culpadas, e submissão e resignação em todos. Um novo povo parece surgir com um novo rei (Bolingbroke, 1997, p. 251).

Mas Bolingbroke também adaptou ao contexto do "momento oligárquico" a doutrina patriarcal: afinal, defensor da construção e dos valores republicanos, o rei era também o pai da pátria. Assim como uma família cuja cabeça e membros estavam unidos e animados por um espírito e interesse comum, a nação encontrava em seu príncipe um pai bondoso e protetor, que deveria servir de centro de uma grande união nacional, a fim de que sua voz fosse ouvida pelo povo sobre as divisōes partidárias: "Porque a facção está para o partido como o superlativo está para o positivo: o partido é o mal político e a facção é o pior de todos os partidos". Revertendo as políticas corrompidas das facçóes, o rei incentivaria a indústria e evitaria mais dívidas; zelaria pela honestidade; desmobilizaria exércitos; pouparia a naçâo de guerras inúteis; e revelaria decência e probidade em seu comportamento. $\mathrm{O}$ rei eventualmente poderia favorecer um partido e desencorajar outro, quando a situação exigisse, mas jamais se filiaria a algum, nem agiria para proscrever o outro: "Ao invés de endossar as divisóes do seu povo, ele tentará uni-lo, sendo ele mesmo o centro dessa uniáo; ao invés de se colocar à frente de um partido para governar seu povo, ele se colocará à frente de seu povo para governar, ou melhor, dizendo, subjugar todos os partidos" (Bolingbroke, 1997, pp. 257-258).

A interpretação da crise política inglesa oferecida por Bolingbroke recupera, assim, temas clássicos de sua leitura de Maquiavel, como a razão de Estado, o combate à corrupção das instituiçóes e o apelo final ao príncipe virtuoso capaz de regenerá-las contra os inimigos da república e retornar aos princípios da Constituição (Pocock, 1971, p. 134). Esse modelo de interpretação republicana está associado, em
Bolingbroke, à reação aos efeitos perversos da riqueza material: as oligarquias destroem o compromisso do cidadão virtuoso com a coisa pública em benefício do interesse cúpido de enriquecimento, o que leva necessariamente a república à corrupção. $\mathrm{O}$ facciosismo, resultante da fragmentação de interesses privados, leva à cooptaçáo das instituiçóes, e apenas a superação dos interesses privados por um ator político integralmente público, o rei, seria capaz de superar a crise republicana vivida pela Inglaterra.

\section{Ideologias do "momento oligárquico" britânico (2): Hume e a interpretaçáo "moderna" ou liberal da Constituiçáo da Inglaterra}

Fundada no ideal de um Estado de direito compatível com a moderna sociedade comercial inglesa, a segunda interpretação da Constituição da Inglaterra começou a ser desenvolvida na virada para o século XVIII, quando whigs situacionistas como Daniel Defoe e Joseph Addison mobilizavam argumentos "modernos" para justificar a "revoluçâo financeira" e a manutenção de exércitos profissionais. Alegavam, contra o republicanismo cívico, que, sujeito a uma dinâmica de progresso, o mundo não podia ser regulado por exigências éticas de virtude cívica criadas em passado remoto; que a liberdade constitucional não era antiga, mas recente, datando da própria Revolução; que o progresso econômico permitia aos cidadãos abandonarem as milícias para pagarem militares profissionais; que a propriedade fundiária havia sido absorvida pelos mecanismos do dinheiro, do crédito bancário e do papel-moeda; que as paixóes e os interesses podiam ser canalizados para civilizar os costumes e garantir as liberdades que impulsionavam a economia.

Algumas décadas depois, os intelectuais patrocinados pela oligarquia whig liderada por Walpole defenderam seu modelo de governabilidade baseado na "corrupção". Políticos dublês de intelectuais, como o bispo Hodley, Lorde Hervey, Thomas Gordon e o próprio irmão de Walpole, Horace, sustentavam contra Bolingbroke que a classe política continuava dividida entre whigs constitucionais e tories absolutistas; que a distribuição 
de cargos, pensões e subornos se tornara o único meio de preservar a influência da Coroa e o caráter misto da Constituição, em uma época em que os comuns já dominavam 17/20 da economia britânica; que a separação entre Coroa e Parlamento não poderia ser absoluta, sob o risco de gerar paralisia decisória; que a interpretação constitucional de Bolingbroke era subversiva porque exclusivamente democrática (Pocock, 1997, pp. 439-494; Hampsher-Monk in Skinner e Van Gelderen, 2002, p. 105). Em A liberdade dos antigose dos modernos estabelecida e comparada (1734), Hervey afirmava de maneira paradigmática que o feudalismo não passara de uma época de sujeição e barbárie; que a Constituição não radicava na antiguidade e estivera em constante fluxo até seu estabelecimento definitivo pela Revolução Gloriosa. A sociedade civil resultava de um "progresso histórico" decorrente da garantia da propriedade privada, da divisão do trabalho e da troca de mercadorias. A virtude cívica era substituída pela polidez como qualidade essencial na sociedade moderna orientada pela noção de progresso histórico (Kramnick, 1968, pp. 111-136; Wootton in Norton e Taylor, 2009, p. 468).

A crença na possibilidade de uma ciência política moderna, de caráter liberal e moderada, encontrou sua expressão na filosofia de David Hume. Ele era um destacado defensor da ordem monetária criada pela "revolução financeira" e do processo de secularização, que convertia homens crentes em milagres em atores de uma história civil. Elaborados a partir do repertório whig oposicionista, produzido ao tempo da "revolução oligárquica", seus Ensaios politicos (1739-1745) representaram a resposta mais consistente à interpretação constitucional formulada por Bolingbroke. Hume condenava tanto o absolutismo quanto o radicalismo como resíduos anacrônicos de duas concepçóes teológicas de mundo: a superstição e o entusiasmo. Ao aceitar as formas e poderes estabelecidos como naturais e a vontade do príncipe como fonte única da autoridade, à maneira de Filmer, o absolutismo dos velhos tories emulava o ideal hierárquico do catolicismo, para quem o conhecimento exigia a intermediação de padres, igrejas e rituais. Já o radicalismo incorria no erro de Locke e outros velhos whigs, para quem a legitimidade da ordem repousava sobre um democratismo contratual baseado em direitos naturais. Para Hume, a estabilidade do Estado de direito dependia de afastar da política crenças baseadas em fundamentos teológicos ou metafísicos, próprias de países atrasados. A civilização moderna criara uma sociedade baseada na polidez, que era impulsionada pelo progresso das ciências e pelas artes, pela proteção dos direitos e pelo intercâmbio de mercadorias. A secularização impunha, por conseguinte, reconstruir a ciência política pela introdução do método experimental. Só ela suprimiria a falsa dicotomia entre liberdade e autoridade, independência e coerçáo, direitos e deveres, demonstrando sua interdependência e a necessidade de um projeto conciliatório que assegurasse estabilidade e longevidade ao regime constitucional (Berkeley e Hume, 1984, p. 172; Hume, 2003, pp. 58-62; Pocock, 1985, pp. 126 e 203; Haakonssen (in Norton e Taylor, 2009, pp. 366-367).

Com o objetivo de substituir formas religiosas e metafísicas de pensamento por uma teoria secular da natureza humana, Hume adaptou o ceticismo pirrônico para o contexto do "momento oligárquico". Ele entendia que a distinção entre o bem e o mal não podia ser feita pela razão; produzidas exclusivamente pelos hábitos, as crenças humanas eram falíveis e incapazes de discernir regras morais e políticas universais (Wiley, 2012, pp. 16 e 32-33). Era preciso, portanto, substituir a postura normativa e metafísica por outra, cética e realista, que levasse em conta a experiência e a observação dos costumes e a diversidade de circunstâncias e situaçóes:

Enquanto uma imaginação ardorosa for admissível em filosofia, e enquanto se aceitar que hipóteses possam ser abraçadas meramente por especiosas e agradáveis, jamais poderemos ter princípios firmes ou sentimentos adequados à prática e à experiência comuns (Hume, 2009, pp. 299).

Nâo havia mais, na origem da vida política, uma essência a que se poderia remontar por meio de uma revolução/restauração; o que havia era uma história na qual o presente ganhava autonomia em relação ao passado. A regularidade do mundo social dependia de instituiçóes que não surgiam da vontade ou na natureza, mas da conformação e adaptação de hábitos coletivos. Governos não se apoiavam em contratos originários ou de acontecimentos remotos, mas em 
rotinas ancoradas na percepção de justiça das regras relativas ao direito de propriedade e aos contratos (Hume, 2003, p. 21). Governos eram legítimos e dignos de confiança desde que preservassem as condiçôes de desenvolvimento econômico da sociedade, que era dotada de uma lógica própria e historicamente variada. Nem por isso, cético como era, Hume acreditava em uma ciência política infalível: se, por um lado, autores como Maquiavel já não podiam ser seguidos acriticamente no presente, por outro, ainda era cedo para pretender, em matéria política e moral, a certeza das ciências físicas e naturais.

O mundo ainda é muito jovem para que estabeleça muitas verdades gerais em política que possam permanecer verdadeiras até a mais distante posteridade. Não tivemos nem mesmo três mil anos de experiência; de maneira que não somente a arte do raciocínio e ainda defeituosa nessa ciência, assim como em todas as outras, mas também carecemos de material sobre o qual possamos raciocinar. Não se sabe ao certo qual o grau de refinamento, seja uma virtude um vício, a que a natureza humana é suscetível; nem o que se pode esperar dos homens após uma importante revolução em sua educação, costumes ou princípios (Hume, 2003, p. 64).

Preso entre um mundo que se extinguia e outro ainda por nascer; situado entre as exigências de equilíbrio entre autoridade e liberdade, tradiçấo e novidade, o pensamento político carregava a marca da ambivalência: "Em todos os governos há uma luta perpétua e entranhada, aberta ou secreta, entre autoridade e liberdade, mas nenhuma das duas pode prevalecer na disputa" (Hume, 2003, pp. 29-30). Autoridade e liberdade careciam de ser mantidas em equilíbrio. O processo de civilização dependia de um conjunto de instituiçóes criadas pela experiência e pelo costume, identificadas com a autoridade do Estado; só elas eram capazes de conferir racionalidade pública ao dinamismo das forças desencadeadas pelas paixóes em um sistema de liberdade (Pocock, 1985 , pp. 134 e 135). Por outro lado, o receio de que o excesso de liberdade comprometesse o processo civilizatório pelo facciosismo recomendava cautela contra o radicalismo: instituiçóes que distribuíam justiça em um ambiente de ordem não deveriam ser sacrificadas a um ideal de perfeição: "O espírito de inovação é em si mesmo pernicioso, por mais favorável que seu objeto possa parecer”. Os políticos deviam ser sensíveis às circunstâncias, preservando os costumes e polindo o padrão do debate para que as disputas sobre a Constituição se transmudassem em disputas no interior da Constituição: "A única regra do governo conhecida e reconhecida pelos homens é o uso e a prática. A razão é um guia tão inseguro que é sempre passível de dúvida e questionamento" (Hume, 2003, p. 252). Conforme ensinara Montaigne, ao invés de dedicar-se a lucubraçôes abstratas, o indivíduo deveria aceitar a ordem política e revalorizar o cotidiano: "Cuidemos de nosso governo tradicional e o aperfeiçoemos na medida do possível, sem encorajar a paixão por novidades perigosas" (Hume, 2003, p. 25).

A filosofia humana é parte de um contexto mais amplo daquilo que se convencionou chamar o iluminismo britânico (Himmelfarb, 2005; Pocock, 1999). Baseado nas ideias da precedência da sociedade civil na organização da vida moderna, no primado da experiência e na imprevisibilidade dos processos políticos para a criação das instituiçóes, na crítica à política fundada em teorias universais e metafísicas como fonte da ação política, o iluminismo britânico, a despeito de suas diferenças internas, oferecerá uma nova linguagem ao pensamento político inglês para descrever a ruptura operada pela emergência $\mathrm{da}$ "sociedade do comércio e das luzes" no interior da Europa, fragmentada por dois séculos entre as soberanias reais e as guerras de religiāo. Os afetos e sentimentos naturais que impelem o homem à vida em sociedade são também parte do argumento que reafirma as liberdades privadas como condição da legitimidade política moderna.

\section{O rei patriota posto à prova: poder pessoal, instabilidade e populismo na primeira década do reinado de George III}

Com a subida de George III ao trono em 1760, chegou ao fim o modelo de governabilidade criado pela oligarquia whig. O novo rei esposava a interpretação da Constituição deixada por Bolingbroke, já admirada 
por seu falecido pai, o príncipe de Gales, e seu principal confidente, o conde de Bute. Eles condenavam o tipo de governação impressa por Walpole e seus sucessores ao longo de meio século, pondo a Coroa na vergonhosa sujeição a uma facção. George III restabeleceria o ideal republicano do governo acima das facçóes; combatendo a dívida pública, os exércitos profissionais e as sinecuras, ele faria de seu palácio "a residência da verdadeira devoção e da virtude" e restauraria afinal a Constituição "ao seu antigo estado de liberdade" (Black, 2008, p. 71). Aconselhado por Bute, o novo rei desfechou o "golpe de Estado" preconizado por Bolingbroke: desalojou a oligarquia whig, acabou com a proscrição dos tories e formou um ministério de conciliação, sem consideração das conexóes partidárias. $\mathrm{O}$ impacto do desmonte do antigo modelo de governação sobre o sistema político foi imediato. As velhas lideranças whigs perderam o controle da agremiação, que se fracionou nas várias facções chefiadas por Grafton, Chatham, Grenville e Rockingham. O fim do ostracismo também acabou com a coesão dos tories, liberados para se recomporem como bem entendessem (O’Gorman, 1997, pp. 151 e 202). O núcleo da nova elite dirigente passou a ser composto pelos chamados "amigos do rei”, espécie de "partido da Coroa", identificado pelos whigs aos tories na medida em que repetiam a tradicional retórica antipartidária que valorizava a Coroa, a Igreja Anglicana e a Câmara dos Pares.

George estava influenciado pelo conceito de governo patriarca implícito no livro de Bolingbroke, bem como no Livro dos Reis do Antigo Testamento que servia de base para muitos sermóes setecentistas. Ele acreditava que, mantendo seu direito de escolher ministros e sua habilidade de bloquear a legislação, estivesse certo de que poderia se desincumbir de suas funçóes e agir de modo apropriado. A esse respeito, George tentou concretizar as esperanças outrora depositadas em seu pai, que o havia encorajado. O rei deveria agir como um redentor político, uma noção que refletia o elemento poderosamente otimístico na iconografia da realeza, presente [...] nas teses de Bolingbroke (Black, 2008, pp. 10-11).
Mas a década de 1760 foi de grande instabilidade. O novo modelo de governaçáo baseado no poder pessoal do rei produziu uma sucessão de gabinetes fracos, que enfrentaram no plano externo a guerra dos Sete Anos e, no interno, o descontentamento decorrente da crise econômica. A conjuntura favoreceu o radicalismo urbano liderado pelo deputado John Wilkes, que atacava o establishment de modo desabusado para defender reformas democráticas, sustentando que a soberania do povo estava fora do Parlamento. Acusado de libertinagem e incitação à desordem, o aventureiro Wilkes protagonizou uma epopeia de condenaçóes judiciais e fugas espetaculares que angariaram o apoio das multidóes para suas demandas radicais por ampliaçáo dos direitos de liberdade de imprensa, de devido processo legal e de reforma parlamentar (McCahill in Jones, 1989, p. 193; O'Gorman, 1997, p. 226; Black, 2001, p. 91; Hampsher-Monk in Skinner e Van Gelderen, 2002, p. 663). O ambiente de crise continuada favorecia a contestação, pelas oposiçóes, do novo sistema "republicano" ou "patriótico" de governação de George III, atacado como autoritário, retrógrado e ilegítimo. Ao mesmo tempo, as guerras de expansão colonial nas diversas partes do mundo, que obrigava a Coroa a aumentar por toda a parte impostos e centralizar a arrecadação para financiar sua marinha e seu exército, esbarraram na resistência dos colonos americanos do outro lado do oceano. Instalou-se então uma escalada de conflitos entre uma metrópole que entendia dever exigir dos americanos que contribuíssem para a manutenção dos exércitos que os protegiam dos vizinhos indígenas, espanhóis e franceses, de um lado, e das treze colônias que entendiam que não deveriam dispender um centavo que fosse antes que tivessem representantes no Parlamento britânico, de outro. Inicialmente fundamentada no constitucionalismo histórico, a linguagem de resistência ao aumento de impostos gradativamente deslizou para aquela do radicalismo produzido na própria metrópole, resistindo os colonos recorrendo à ideologia republicana clássica de resistência à tirania desenvolvida por aqueles que seriam vistos retrospectivamente como velhos whigs radicais seiscentistas como Harrington, Sidney e Locke (a despeito do fato de que a expressão "partido whig", empregada para designar a oposição 
à sucessão ao trono por Jaime II, já existia ao tempo da Querela Exclusionista, e Sidney e Locke já eram em vida a ele associados). Apoiada pela maior parte dos radicais britânicos, como o republicano Thomas Paine, a independência dos Estados Unidos da América foi seguida por uma onda de reorganizaçáo político-institucional das antigas colônias que, embora não tenha durado, refletia a engenharia institucional radical que consagrava executivos fracos, legislativos unicamerais fortes e um decidido repúdio aos exércitos profissionais e qualquer tipo de centralização política. Tratava-se de uma forte advertência ao establishment político britânico sobre as consequências tanto do radicalismo quanto da fraqueza de um governo monárquico sem apoio na opiniāo pública (Pocock, 1997; Wood, 1998).

\section{$O$ governo representativo entre a autoridade $e$ a liberdade: Edmund Burke e as modulaçóes do liberalismo moderado}

A polarização entre radicalismo democrático e autoritarismo monárquico na Grã-Bretanha exigia uma resposta política dos moderados, na forma de uma defesa de um prudente reformismo. Durante o período de hegemonia dos "homens de rei", como Bute e Lorde North, a antiga coalizão whig que dominara o Parlamento durante a primeira metade do século XVIII britânico havia se fragmentado em facçôes diversas, a principal das quais, na oposição, era liderada pelo marquês de Rockingham. Seu principal doutrinário, Edmund Burke (1727-1797), reivindicou para eles a condição de herdeiros das tradiçóes do partido e começou um processo de decantaçẫo e adaptação da filosofia identificada com Hume para o contexto de uma cultura política estruturada pelo antagonismo entre "campo" (oposição) e "corte" (situaçâa). Na qualidade de membro da Câmara dos Comuns, doutrinário e polemista, Burke adaptou como ninguém a imagem do estadista clássico identificada com Cícero para o contexto da política britânica setecentista. Dotado de extraordinária cultura e erudiçáo, o político irlandês estava familiarizado com o mundo antigo, conhecendo o repertório da retórica e da eloquência e manuseando a literatura clássica de modo a conseguir efeitos literários notáveis. Mas Burke estava também ancorado no mundo moderno, no qual uma aristocracia fundiária gerencial mobilizava o sistema de crédito público para estimular a prosperidade comercial, a estabilidade política e o poder imperial. Ele estava alinhado a outros pensadores do iluminismo britânico, como Hume, Millar e Adam Smith (cujo círculo frequentava desde que escrevera Uma investigação filosófica sobre a origem de nossas ideias do sublime $e$ do belo), comprometidos com o projeto de uma economia política, isto é, uma ciência social nascida da sociedade comercial e financeira, entendida como parte de uma filosofia da moral natural cada vez mais historicizada. Essa combinação harmoniosa entre antiguidade e modernidade se refletia na concepção que Burke guardava da Constituiçáo da Inglaterra. Por um lado, ele esposava a tese dos constitucionalistas antiquários de que ela datava da Idade Média e era obra da "sabedoria de nossos ancestrais", que, ao estabelecerem a Constituição mista, teriam assegurado os "direitos imemoriais" dos britânicos. Por outro, ele concordava com os "modernistas" ao reconhecer que ela era um produto histórico, dotada de flexibilidade bastante para adaptar-se ao progresso social, e que graças a ela a Constituição revelara-se resiliente ao longo do tempo na defesa daquelas liberdades (Pocock, 1984).

Esse competente cruzamento entre o clássico e o moderno produziu o arquétipo do estadista whig virtuoso, que seria cultuado e emulado durante todo o século seguinte por uma legião de políticos dentro e fora da Inglaterra, como Macaulay, Russell, Guizot, Gladstone e Disraeli (O'Brien, 1968, p. 49; Bord, 2009, pp. 35-39). À semelhança de Cícero, Burke se pensava como "um filósofo em ação", apartado tanto do demagogo quando do filósofo de gabinete (Burke, 1993, p. 187).

Um estadista difere de um professor em uma universidade; o último tem apenas a visão geral da sociedade; o anterior, o estadista, tem um número de circunstâncias para combinar com essas ideias gerais e para levar em consideração. As circunstâncias são infinitas, são infinitamente combinadas; são variáveis e transitórias; aquele que não as leva em consideração, não só está errado, 
mas louco - dat operam ut cum ratione insaniat-; ele é metafisicamente louco. Um estadista, nunca perdendo de vista os princípios, deve ser guiado pelas circunstâncias; e se julgar de modo contrário às exigências do momento, pode arruinar o seu país para sempre (Burke, 1906, p. 317).

Essa flexibilidade estava no coração daquilo que Burke compreendia como próprio da prudência do estadista, guiado por uma experiência esclarecida pelo conhecimento histórico e pela avaliação cuidadosa das circunstâncias. Era ela que o acautelava contra a “ilusória precisão geométrica em matéria de argumentos morais" (Burke, 1993, p. 258). A política não era uma ciência abstrata, racionalista e universalista, mas uma arte voltada para a resolução de problemas práticos. Cada nação - Inglaterra, Irlanda, Estados Unidos, Índia, França - compreendia uma ecologia própria, que condicionava o ritmo da ação política: regras ou posturas que funcionavam em certos tempos e lugares não funcionavam em outros. Para conseguir manter o equilíbrio instável entre autoridade governamental e liberdade popular, de que a Constituição da Grã-Bretanha exigia para subsistir, o estadista deveria saber em que circunstâncias precisa favorecer esta ou aquela: "Nossa Constituiçáo repousa sobre um belo promontório, cercado por precipícios íngremes e águas profundas em todos os lados. Ao removê-la de uma inclinação perigosa para um lado, pode haver risco de precipitá-la, por outro" (Burke, 1993, p. 190).

Assim, o liberalismo moderado de Burke oferecia uma identidade whig que a localizava entre os tories que, à direita, como "partido da Corte", valorizavam a "independência da Coroa", e os radicais que, à esquerda, como "partido democrático", insistiam na soberania popular extraparlamentar (Pocock, 1985, pp. 158-159, 209 e 258). No começo de sua carreira, Burke se colocou na defesa da liberdade contra a oligarquia conservadora de Jorge III, defendendo os partidos e o governo parlamentar, as liberdades dos colonos contra o centralismo metropolitano e denunciando os abusos da administração imperial na Índia. Já no final de sua carreira, diante da ameaça do radicalismo revolucionário francês, ele advogaria a adesão dos whigs ao governo tory de William Pitt e combateria o ideário universalista e abstrato que se espraiava pela Inglaterra. Burke reconhecia que o ziguezague era arriscado para o político: "Se ele for obrigado a responsabilizar os favoritos do povo, será considerado ferramenta do poder; se ele censurar os que estiverem no poder, receberá a pecha de instrumento de facção" (Burke, 1993, p. 116). Mas ele acreditava também que o estadista tinha deveres morais para com a comunidade, de que não podia se furtar sem prejuízo da própria honra.

O melhor exemplo de modulação da doutrina whig em favor da liberdade contra a autoridade nesse período encontra-se no panfleto Pensamentos sobre as causas dos atuais descontentamentos (1770). Congruente com as postulaçóes de Hume, Burke acreditava que a crença bolingbrokeana de que o bem comum fosse perfeitamente discernível por homens dotados de razão repousava sobre uma concepção ultrapassada de mundo social. Havia interesses sociais legítimos que deveriam ser considerados pelo governo, à cuja testa precisavam estar estadistas dotados de espírito de transigência: "Todo governo, de fato todo benefício e gozo humanos, toda virtude e todo ato prudente, é fundado em compromisso e troca" (Burke, 1993, p. 237). O reconhecimento da pluralidade social o levava a crer que, ao invés de conduzida exclusivamente pelo ideal de bem comum interpretado pelo "rei patriota", as açóes do governo deveriam ser reguladas pelos humores da opinião pública. $\mathrm{O}$ bom governo não era apenas constitucional, no sentido de garantir a autonomia da sociedade; ele também precisava ser representativo, valorizando aquilo que os cidadãos privados pensavam a respeito da condução adequada dos negócios públicos (Burke, 1993, p. 117).

Por outro lado, embora crítico do governo pessoal do monarca, Burke não incorria no excesso oposto dos radicais, para quem os deputados eram meros porta-vozes de seus eleitores. Pensando a classe política como um estrato mais preparado e competente do que ambos, ela deveria saber evitar "os perigos extremos da submissão servil ou da popularidade selvagem" (Burke, 2012, p. 101; Pitkin, 1967, p. 168). Seja como for, uma vez que a opinião pública não podia ser descartada como facciosa, os partidos também não poderiam ser reduzidos, como também pretendia Bolingbroke, à condição de facçôes egoísticas a serem esmagadas pelo "rei patriota". Na qualidade de correias 
de transmissão entre representantes e representados, Burke dignificava os partidos como agrupamentos de cavalheiros reunidos legitimamente "para fomentar, mediante açóes conjuntas, o interesse nacional, com base em algum princípio acerca do qual estão todos de acordo" (Burke, 1993, p. 187). A influência política dos aristocratas era perfeitamente legítima, na medida em que fosse natural, ou seja, desde que adquirida "por sua conduta uniforme, correta e constitucional, por suas virtudes públicas e particulares" (Burke, 1993, p. 134).

Tudo bem pesado, Burke condenava a doutrina bolingbrokeana adotada pelos "amigos do rei" como uma cortina de fumaça, através da qual uma cabala, partido da Corte ou facção áulica, armada com o poder pessoal do monarca, alijava do governo homens e partidos representativos da opinião pública, substituindo-os por ministérios subservientes e inexpressivos que lhe servissem de marionetes (Lee in Dickinson, 2002, p. 75; Elofson, 1996, p. 3; Black, 2001, p. 368). A pretensão de libertar o "rei patriota" das facções resultara em um modelo inconstitucional de governo: “O poder discricionário da Coroa na formação do ministério, abusado por maus ou fracos homens, deu origem a um sistema que, sem violar a letra da lei, opera contra todo o espírito da Constituição" (Burke, 1993, p. 143). Ao sugerir que a Constituição não era apenas forma, mas um espirito, Burke estabelecia uma distinção entre legalidade e legitimidade, que posicionava o conceito de opinião pública como novo referente interpretativo da Constituição britânica. Abandonava-se a interpretação da Constituição mista à moda clássica, baseada no equilíbrio entre as ordens da monarquia, aristocracia e democracia, para vê-la à maneira moderna de um governo parlamentar no qual aqueles três elementos passavam a ser concebidos principalmente como instituiçóes - Coroa, pares e comuns - cuja legitimidade dependia de sua capacidade de exprimir os anseios da opinião pública (Mansfield, 2013, p. 129; Craig in Dwan e Insole, 2012, p. 109).

Nessa nova interpretação whig do governo representativo, quem ganhava relevo era a Câmara dos Comuns: porque composta por deputados eleitos, ela se tornava, nas palavras de Burke, a "imagem expressa dos sentimentos da nação" (Burke, 1993, p. 160). Embora legal, a prerrogativa de livre nomeação e demissão dos ministros pela Coroa só era legitima e, portanto, verdadeiramente constitucional, na medida em que escolhesse para o governo homens sintonizados com os sentimentos do país. Ao contentar-se com mudanças que fortalecessem o caráter representativo do governo, os whigs interpretados por Burke logravam fazer a defesa da liberdade de expressão dos radicais, sem se comprometerem, todavia, com seu pleito por reformas constitucionais.

\section{Conclusão}

Enquanto a oposição tory se prendia ao repertório do humanismo renascentista, a situação whig buscava adaptá-lo às novas exigências de uma sociedade comercial. A linguagem do liberalismo começou a ser talhada por aqueles "modernos", menos como uma ideologia oligárquica alternativa do que como consequência dos esforços de adaptar, atualizar ou reconfigurar um republicanismo percebido como anacrônico em face das demandas do capitalismo em expansão (Pocock, 1985). Em contraste com as linguagens oposicionistas da "revolução oligárquica", que exaltavam a liberdade dos cidadáos, o bloco whig alinhado com Walpole elaborou as bases de um liberalismo situacionista que, para enfatizar a importância da autoridade governamental como fiadora da Constituição, recuperou e adaptou certas categorias do "momento monárquico", como as da razão ou do segredo de Estado; para justificar a falta de publicidade para as decisóes diplomáticas; e a da prerrogativa monárquica, a fim de empregá-la em caso de guerra ou motins. Náo ficou de fora o olhar demofóbico, que justificava a circunscrição dos limites legítimos da atividade política aos círculos do governo e do Parlamento, desqualificando as manifestaçóes oposicionistas de rua como expressão inequívoca da tolice e inconstância do povo.

É a partir do século XVIII que vários intérpretes das transformaçôes correntes na "Europa do comércio e das luzes" irão vincular a afirmação do progresso material ao progresso moral das sociedades. A expressão mais célebre dessa interpretação encontra-se na obra de Adam Smith, que apresenta a relação entre o progresso social e a existência de um "espírito comercial" 
responsável por domesticar os costumes, arrefecer a guerra e transformar as relaçóes entre as nações.

O comércio e as manufaturas introduziram gradualmente a ordem e o bom governo, e com eles a liberdade e a segurança dos indivíduos, entre os habitantes do campo, que haviam antes vivido numa condição quase contínua de guerra com seus vizinhos e de dependência servil com relação a seus superiores. Isto, apesar de ter sido a última coisa a ser observada, é o mais importante de seus efeitos. O Sr. Hume é o único escritor que, até onde eu sei, percebeu anteriormente isto (Smith, 1976, p. 322).

O que resulta dessa união entre a ideia de progresso e o desenvolvimento do comércio e da indústria é o conceito de civilização tão caro ao iluminismo britânico: ele passa a descrever uma "condição moral" encontrada em determinados povos que atendem a determinados critérios ao mesmo tempo que descreve o percurso desses povos no tempo histórico. A "sociedade civil" não tem o sentido que possui com Locke, onde se definia por oposição ao estado de natureza, nem o sentido que terá com Hegel, definindo-se por oposição ao Estado (Rosanvallon, 2002). O adjetivo "civil" não é compreendido senão com referência ao processo dessa nova civilização que representa uma inevitável ruptura com as representaçóes que davam sentido às experiências políticas precedentes.

Mas esse complexo processo de constituição de uma linguagem política para dar conta dos processos sociais, culturais e econômicos emergentes no século XIX, que implicou a criação de novos conceitos e a ressignificação de antigos, não ocorreria do dia para a noite. Ao contrário, as duas linguagens - a do republicanismo e a do liberalismo - permaneceriam amalgamadas por cerca de um século, fosse no radicalismo de Paine e Sieyès, ou no moderantismo de Constant e Tocqueville, até que o humanismo cívico fosse sepultado pela onda cientificista da década de 1860, embalada por autores como Spencer, Comte e Marx. No período aqui examinado, todavia, esse processo estava começando: a Grä-Bretanha era ainda uma sociedade transicional marcada por um "humanismo comercial”, na qual já não era possível retornar à antiga virtude clássica, tampouco a substituir de todo pelas paixóes de um capitalismo ainda em botão. As formulaçôes iniciais do liberalismo britânico setecentista tematizaram problemas sociais e políticos emergentes com a sociedade comercial - como o interesse privado e as novas formas de progresso material para o enriquecimento dos povos-, apontando para a ineficiência das antigas concepçóes da vida política identificadas com a crítica aos partidos como facçóes de interesses privados e a valorização da ação virtuosa do monarca. As ideias de um bom governo, dotado de instituiçóes e fundado na virtude, não foram abandonadas, e sim redimensionadas para harmonizá-las com os interesses privados e a concepção emergente de progresso do século XVIII (Hampsher-Monk in Skinner e Van Gelderen, 2002, p. 86-89).

\section{BIBLIOGRAFIA}

ARMITAGE, David. (2002), "Empire and liberty: a republican dilemma", in Q. Skinner; M. Gelderen (eds.), Republicanism: a shared European heritage. V. I: Republicanism and constitutionalism in early modern Europe, Cambridge, Cambridge University Press.

BAILYN, Bernard. (2003), As origens ideológicas da Revolução americana. Edição ampliada. Tradução de Cleide Rapucci. Bauru, Edusc.

BALL, Terence; FARR, James \& HANSON, Russell (eds.). (1989), Political innovation and conceptual change. Cambridge, Cambridge University Press.

BERKELEY, George; HUME, David. (1984), Tratado sobre os principios do conhecimento humano; Três diálogos entre Hilas e Filonous em oposição aos céticos e ateus; Investigação sobre o entendimento humano; Ensaios morais, politicos e literários. Traduçóes de Antônio Sérgio, Leonel Vallandro, João Paulo Gomes Monteiro e Armando Mora d'Oliveira. São Paulo, Ed. Abril.

BERLIN, Isaiah. (1969), Four essays on liberty. Oxford, Oxford University Press.

BIGNOTTO, Newton. (2001), Origens do republicanismo moderno. Belo Horizonte, Ed. UFMG. 
BIGNOTTO, Newton. (2006), Republicanismo e realismo: um perfil de Francesco Guicciardini. Belo Horizonte, Ed. UFMG.

BLACK, Jeremy. (2001), Walpole in power. Gloucestershire, The History Press.

BLACK, Jeremy. (2008), George III: America's last king. New Haven/London, Yale University Press.

BOLINGBROKE, Henry St. John, Viscount of. (1997), Political writings. Edited by David Armitage. Cambridge, Cambridge University Press.

BORD, Joe. (2009), Science and whig manners: science and political style in Britain, c. 1790-1850. London, Palgrave MacMillan.

BURKE, Edmund. (1906), The works of the right honorable Edmund Burke. Oxford/London, Oxford University Press. V. III.

BURKE, Edmund. (1993), Pre-revolutionary writings. Edited by Ian Haris. Cambridge, Cambridge University Press.

BURKE, Edmund. (2012), "Discurso aos eleitores de Bristol". Revista de Sociologia e Política, 20 (44): 97-101.

DICKINSON, H. T. (ed.). (2002), A companion to eighteenth century England. London, Blackwell Publishers.

DWAN, David \& INSOLE, Christopher (eds.). (2012), The Cambridge companion to Edmund Burke. Cambridge, Cambridge University Press.

ELOFSON, W. M. (1996), The Rockingham connection and the second founding of the Whig Party (1768-1773). Montreal, McGill-Quenn's University Press.

GOLDIE, Mark \& WOKLER, Robert (eds.). (2008), The Cambridge history of eighteenth-century political thought. Cambridge, Cambridge University Press.

HIMMELFARB, Gertrude. (2005), The roads to modernity: the british, french and american enlightenments. New York, Vintage Books.

HUME, David. (2003), Ensaios políticos. Edição de Knud Haakonssen. Tradução de Pedro Pimenta. São Paulo, Martins Fontes.

HUME, David. (2009), Tratado da natureza humana: uma tentativa de introduzir o método experimental de raciocinio nos assuntos morais. Tradução de Déborah Danowski. São Paulo, Ed. Unesp.
JONES, Clyve (ed.). (1989), A pillar of the Constitution: the House of Lords in british politics. London/ Ronceverte, The Hambledon.

KALYVAS, Andreas \& KATZNELSON, Ira. (2008), Liberal beginnings. making a republic for the moderns. Cambridge, Cambridge University Press.

KRAMNICK, Isaac. (1968), Bolingbroke and his circle: the politics of nostalgia in the age of Walpole. Cambridge, MA, Harvard University Press.

LEVINE, Joseph M. (1999), The battle of the books: history and literature in the Augustan age. Ithaca and London, Cornell University Press.

MACPHERSON, C. B. (2011), The political theory of possessive individualism: from Hobbes to Locke. Oxford, Oxford University Press.

MANSFIELD, Harvey C. (2013), Statesmanship and party government: a study of Burke and Bolingbroke. Chicago/London, The University of Chicago Press.

NORTON, David Fate \& TAYLOR, Jacqueline (eds.). (2009), The Cambridge Companion to Hume. 2nd ed. Cambridge, Cambridge University Press.

O'BRIEN, Conor Cruise. (1968), "Introduction", in E. Burke, Reflections on the Revolution in Frances and on the proceedings in certain societies in London relative to that event, London, Penguin.

O'GORMAN, Frank. (1997), The long eighteenth century: british political and social history. London, Hodder Arnold.

PITKIN, Hanna. (1967), The concept of representation. Berkley, University of California Press.

POCOCK, J. G. A. (1971), Politics, language and time. Essays on political thought and history. Chicago, University of Chicago Press.

POCOCK, J. G. A. (1984), Ancient constitution and feudal law. A study in english historical thought in seventeenth century. 2nd ed. Cambridge, Cambridge University Press.

POCOCK, J. G. A. (1985), Virtue, commerce and history: essays on political thought and history, chiefly in the eighteenth century. Cambridge, Cambridge University Press.

POCOCK, J. G. A. (1997), Le moment machiavélien. Paris, PUF. 
POCOCK, J. G. A. (1999), Barbarism and religion. V. 1: The enlightenments of Edward Gibbon (17371764). New York, Cambridge University Press.

QUINTANA, Fernando. (2014), Etica e política: da antiguidade clássica à modernidade. Rio de Janeiro, Atlas.

ROSANVALLON, Pierre. (2002), Le libéraliste utopique. Histoire de l'idée de marchée. Paris, Gallimard.

SKINNER, Quentin. (2012), Liberty before liberalism. Cambridge, Cambridge University Press.

SKINNER, Quentin \& PHILIPSON, Nicholas (eds.). (1993), Political discourses in early modern Britain. Cambridge, Cambridge University Press. SKINNER, Quentin \& VAN GELDEREN, Martin (eds.). (2002), Republicanism: a shared European heritage. V. I: Republicanism and constitutionalism in early modern Europe, Cambridge, Cambridge University Press.

SMITH, Adam. (1976), An inquirity into the nature and causes of the Wealth of Nations. Indianapolis, Oxford University Press. V. 1.

URBINATI, Nadia. (2012), "Republicanism after the French Révolution: the case of Sismonde de Sismondi”. Journal of the History of Ideas, 73 (1): 95-109.

WILEY, James. (2012), Theory and practice in the philosophy of David Hume. Palgrave MacMillan. WOOD, Gordon. (1998), The creation of the american republic. Chapel Hill, University of North Carolina Press. 


\section{AS METAMORFOSES \\ IDEOLÓGICAS DO \\ PENSAMENTO BRITÂNICO \\ SETECENTISTA DO \\ REPUBLICANISMO DE \\ BOLINGBROKE AO LIBERALISMO DE BURKE} (1720-1770)

Christian Edward Cyril Lynch, Paulo Henrique Paschoeto Cassimiro

Palavras-chave: Liberalismo; Republicanismo; Teoria política britânica; Constituição; Governo misto.

O presente artigo explora as transformaçóes e diferenças entre republicanismo e liberalismo nas linguagens políticas do debate britânico setecentista. Pretendemos demonstrar como as dinâmicas próprias ao que estamos chamando de "momento oligárquico" inglês se expressam em linguagens políticas distintas: de um lado, a retomada de certo tipo de republicanismo maquiaveliano volta-se contra o predomínio das oligarquias e apela ao protagonismo da coroa; do outro, a defesa das transformaçóes sociais e econômicas acarretadas pela expansão do comércio e da vida civil conduz ao diagnóstico da incompatibilidade do republicanismo antigo com a modernidade e acentua a necessidade de convivência entre o indivíduo privado e o cidadão moderno. Ao fim, este debate, indissociável de problemas contextuais e históricos do processo político inglês, ilustra uma transformação central para a emergência das linguagens políticas que constituem as ideologias e instituiçóes predominantes $\mathrm{da}$ democracia liberal.

\section{THE IDEOLOGICAL METAMORPHOSIS OF XVIII CENTURY BRITISH THINKING: FROM BOLINGBROKE'S REPUBLICANISM TO BURKE'S LIBERALISM}

Christian Edward Cyril Lynch, Paulo Henrique Paschoeto Cassimiro

Keywords: Liberalism; Republicanism; British political theory; Constitution; Mixed government.

This article explores the transformations and differences between republicanism and liberalism in the political languages of the eighteenth-century British debate. We intend to demonstrate how the dynamics proper to what we are calling the English "oligarchic moment" are expressed in distinct political languages: on the one hand, the resumption of a certain kind of machiavellian republicanism turns against the predominance of oligarchies and appeals to the protagonism of the crown; on the other, the defense of the social and economic transformations brought by the expansion of commerce and civil life leads to the diagnosis of the incompatibility of ancient republicanism with modernity. It also emphasizes the need for coexistence between the private individual and the modern citizen. This debate, inseparable from the contextual and historical problems of the English political process, illustrates a central transformation for the emergence of the political languages that constitute the prevailing ideologies and institutions of liberal democracy.

\section{LES MÉTAMORPHOSES IDÉOLOGIQUES DE LA PENSÉE BRITANNIQUE DU XVIIÈME: DU RÉPUBLICANISME DE BOLINGBROKE AU LIBÉRALISME DE BURKE (1720 - 1770)}

Christian Edward Cyril Lynch, Paulo Henrique Paschoeto Cassimiro

Mots-clés: Libéralisme; Républicanisme; Théorie politique britannique; Constitution; Gouvernement mixte.

Cet article explore les transformations et les différences entre le républicanisme et le libéralisme dans les langages politiques du débat britannique du XVII ${ }^{\text {ème }}$ siècle. Nous avons l'intention de démontrer comment les dynamiques propres à ce que nous appelons le «moment oligarchique " anglais s'expriment dans différents langages politiques: d'une part, la reprise d'un certain type de républicanisme machiavélique se tourne contre la prédominance des oligarchies et fait appel au protagonisme de la couronne; d'autre part, la défense des transformations sociales et économiques causées par l'expansion du commerce et de la vie civile conduit au diagnostic de l'incompatibilité de l'ancien républicanisme avec la modernité et accentue le besoin de coexistence entre l'individu privé et le citoyen moderne. En fin de compte, ce débat, indissociable des problèmes contextuels et historiques du processus politique anglais, illustre une transformation centrale pour l'émergence de langages politiques qui constituent les idéologies et les institutions prédominantes de la démocratie libérale. 